ISBN 978-81-933894-1-6

International Conference on Studies in Disaster Management, Civil and Architectural Engineering

(SDMCAE-17)

Kyoto (Japan) April 18-19, 2017

\title{
A Guidelines for People Capability Enhancement to Support Sustainable Facility Management in Infrastructure Project
}

\author{
Norliana Sarpin ${ }^{1}$, Narimah Kasim ${ }^{1}$ and Rozlin Zainal ${ }^{1}$ \\ ${ }^{1}$ Department of Construction Management, Faculty of Technology Management and Business, Universiti Tun \\ Hussein Onn Malaysia (UTHM), Johor, Malaysia
}

\begin{abstract}
Facility management spans over a considerable length of time and is a key phase in the development cycle of infrastructure assets. Therefore, facility managers are in a commanding position to maximise the potential of sustainability through operation, maintenance and upgrade leading to decommission and deconstruction. Sustainability endeavours in facility management practices will not only contribute to reducing energy consumption, waste and running costs, but also help improve organisational productivity, financial return and community standing of the organisation. At the forefront facing sustainability challenge, Facility manager should be empowered with the necessary knowledge and capabilities. However, literature studies show a gap between the level of awareness, specific knowledge and the necessary skills required to pursue sustainability in the profession. People capability is considered as the key enabler in managing the sustainability agenda as well as being central to the improvement of competency and innovation in an organization. This paper aims to identify the critical factors for enhancing people capabilities in promoting the sustainability agenda in facility management practices focusing in infrastructure project. Starting with a total of 23 critical factors identified from previous questionnaire survey, the authors conducted an interview with experts in facility management who involved directly with infrastructure project to assess the perceived importance of these factors. The findings reveal these 23 critical factors as significantly important to support sustainable facility management in infrastructure project. They form the basis of a mechanism framework developed to equip facility managers with the right knowledge, to continue education and training and to develop new mind-sets to enhance the implementation of sustainability measures in FM practices in infrastructure project.
\end{abstract}

Keywords: capabilities, facility management, infrastructure, people, sustainable development

\section{Introduction}

The construction industry especially infrastructure project had given a significant impact to economy growth, and also generate implications to the environment and social aspect of a country $[1,2,3]$. This industry is facing major environmental challenges worldwide due to its significant impact on the environment. In addition, according to National Research Council of the National Academics [4], infrastructure sustainability is a lifeline resilient, environmentally viable and socially equitable. To generate an effective built environment and achieve sustainable construction along the project life-cycle, more attention should be paid to the occupancy phase especially in facility management practices. Sustainable facility management is a significant environmental challenges and requires a concerted response from all infrastructure project players. According CIOB [5], the energy usage for power and maintenance during operation phase of a built asset alone account for approximately $45 \%$, compared to $5 \%$ used during construction phase. These scenario has increase the demand for sustainable FM to protect ecological processes and protect the wellbeing of future generation. Moreover, sustainability endeavours in FM practices will not only contribute to reducing energy consumption, waste and running costs, 
but also help improve organisational productivity, financial return and community standing of the organisation $[6,7,8]$.

However, despite the growing awareness of sustainability in FM, very few facilities managers and built asset owner positively uptake the sustainability idea and implement them in their operation due to the infancy of sustainability practice in the FM sector [9]. This drawback has lead to a lack of understanding and skills that required to put the sustainability agenda into action. Proper capabilities and skills among FM practitioners can contribute hugely to the success implementation of the sustainability agenda in the FM sector [6, 10]. Yet, FM practitioners still suffer from the lack of capabilities and inconsistency of skills to implement sustainability in their routines. Furthermore, issues such as the lack of sustainability knowledge and also knowledge gap add to the difficulty $[10,11,12]$. Transition to sustainability will not materialise until facility manager were empowered with the necessary knowledge and capabilities in order to face the sustainability challenges [13]. This situation highlights the importance of considering capabilities, skills and knowledge approach as a pathway to enable the management of sustainability agenda.

Therefore, in line with the potential of the FM and sustainability in implementation in infrastructure project, this research investigates the potential people capabilities factors that can assist in the implementation of sustainability agenda in facility management practices focussing in infrastructure project in Malaysia. Through a questionnaire survey done previously, twenty three critical people capability factors were identified. An interpretive structural model for people capability was then developed to identify the priority of critical factor and provide a hierarchical and inter-relational structure among the factors.

This paper focuses on the findings of a semi-structured interview with experts in facility management who involved directly with infrastructure project to assess the perceived importance of the people capability factors. A set of guidelines for action and potential effects of each critical people capability factor was developed through the identification and integration of the different perceptions and priority needs of the experts. The guidelines helps provide directions for facility management personnel who are seeking to encapsulate the sustainability agenda in their practice.

\section{People Capabilities to Support the Implementation of Sustainable Facility Management in Infrastructure Project}

FM professionals are at the forefront of integrating sustainable practices through their operational and management activities. In addition to their technical and operational skills, FM professionals have a great opportunity to make a valuable strategic contribution towards their organisation's sustainable business. However, the concerning issue of limited capabilities in achieving this vision has risen an alarming situation and solutions were needed $[6,10,14]$. Due to this, the FM professionals need to understand and recognise how the growing importance of sustainability is influencing the way they discharge their duties, roles and responsibilities. FM personnel must become professionally competent and knowledgeable about the sustainability issues that will impact on their business environment, both operationally and strategically [14].

In establishing a theoretical knowledge base guide through the data collection and analysis, a background review was conducted to understand what are the people capability (PCap) factors that would impact on the consideration of sustainability measures in facility management practice. This understanding contributed to the establishment of a basis to equip facility managers with the right knowledge and skill that in turn influence the sustainability endeavour in their practices. Previous research by Sarpin and Yang has identified twenty-three (23) critical people capability factors as the important factors in the promotion of sustainability agenda in FM practices $[13,15]$.

The 23 people capability factors were grouped into four categories based on Wiek et al. classification for a similar application, including interpersonal capabilities, system thinking capabilities, anticipatory capabilities, and strategy capabilities as shown in Figure 1 [16]. In this research context, interpersonal capability relates to enabling FM personnel to solve issues and respond to challenges of sustainability applications. System thinking 
is about being able to analyse complex systems across three different pillars of sustainability and over different scales. The anticipatory capability will facilitate analysis and evaluation of sustainability actions and consequences. Finally, the strategic capability will contribute to specific sustainability implementation strategies in an organisation. Together, these 23 factors offer a foundation to equip FM professionals with the skill-set to obtain the right knowledge, education, training and new mind set to boost the implementation of the sustainability agenda in FM practices. The framework can serve as the basis for coordinating the systematic enhancement of sustainability measures in FM practices.

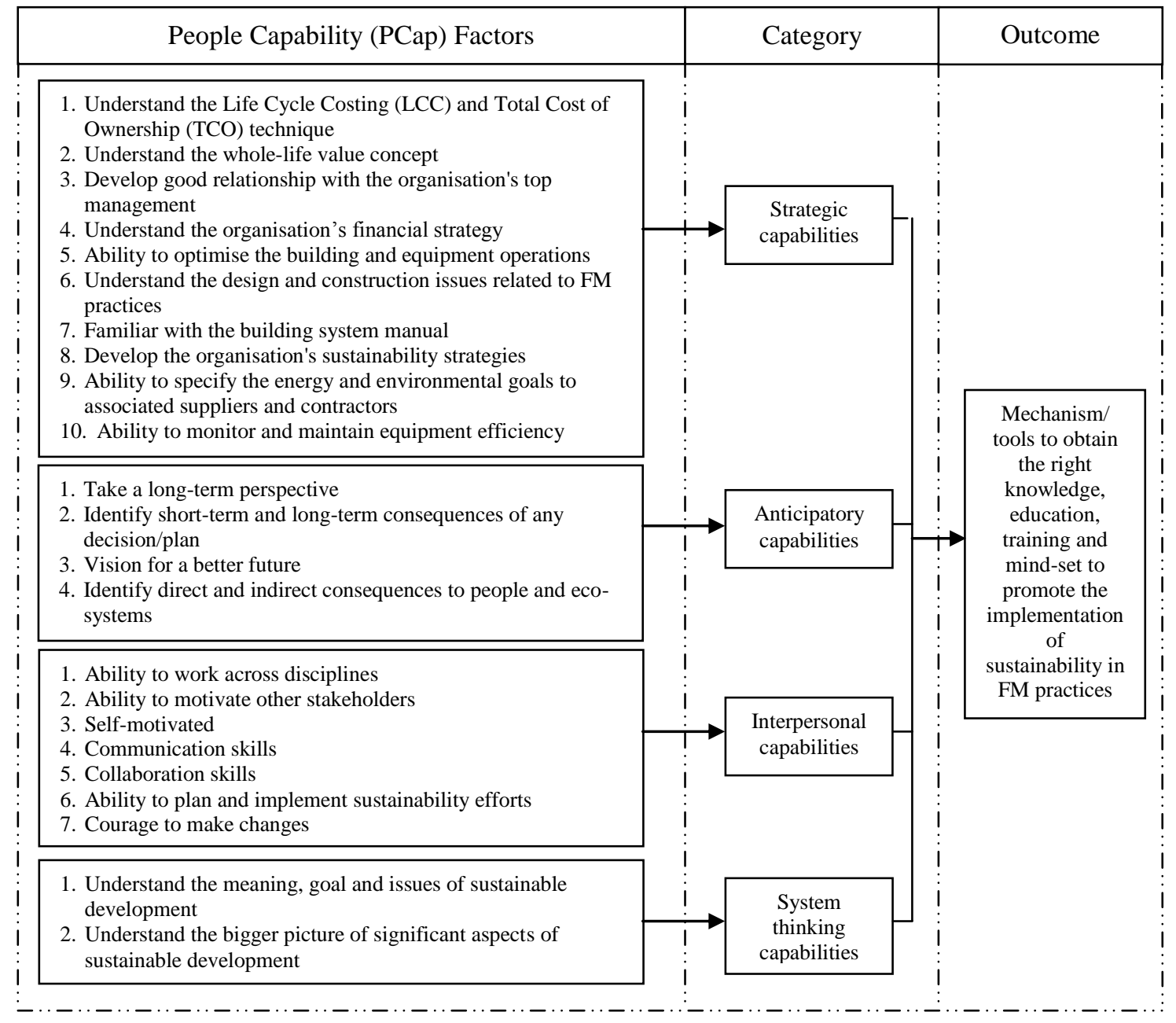

Fig. 1: Conceptual framework for people capabilities in promoting sustainability in FM practices.

\section{Semi-Structured Interview}

In this research, interviews were conducted to gain insights from experienced of facility manager personnel involved in the infrastructure projects. Interviews were conducted to gain insights from experienced personnel involved in the projects. In general, there are three types of interview, namely, unstructured, semi-structured and structured interviews [17]. Unstructured interviews are conducted to help find out what is happening in relation to a particular phenomenon and to seek new insights [18]. In semi-structured interviews, a number of interviewer questions are prepared in advance, however, such prepared questions are designed to be relatively open, which means that subsequent questions must be improvised in a careful and theorised way [19]. According to Robson [20], the order of predetermined questions in semi-structured interviews can be modified, question wording can be changed and questions can be omitted and added based on the interviewer's perception of what seems to be appropriate. Structured interviews are used when the researcher already knows what information is needed. The 
researcher conducts the structured interview with a list of predetermined questions to be asked of the respondents [21]. The structured interview is also used as a means to identify general patterns [18].

For this research, the semi-structured approach was adopted. In this style of interviewing, besides the main questions, a few other sub-questions with the same meaning were also prepared. The questions for the interviews were designed based on the 23 people capability factors identified from the previous study. These questions were designed to assist the interviewees to share their perceptions on how the people capability factors from the framework can help to promote sustainability in FM practices. The questions were developed to meet the objectives of the research. Question 1 was focused on general questions regarding the suitability of the 23 people capability factors and Question 2 sought the respondent's opinions on how the factors can support the sustainable FM practice in the infrastructure project. The main interview questions are set out in Table 1.

TABLE I: INTERVIEW QUESTIONS

\begin{tabular}{ll}
\hline \hline Main question & Sub-Questions \\
\hline 1. General & $\begin{array}{l}\text {-Do you think that the people capability factors proposed are significant } \\
\text { for infrastructure project? }\end{array}$ \\
$\begin{array}{l}\text { 2. How can the people } \\
\text { capability factors promote }\end{array}$ & $\begin{array}{l}\text {-How can the ability to "understand the LCC and TCO technique" } \\
\text { promote sustainability in the infrastructure project? }\end{array}$ \\
sustainability in this project? & $\begin{array}{l}\text {-How can the ability to "understand the whole-life value concept" } \\
\text { promote sustainability in the infrastructure project? } \\
\text { - etc }\end{array}$ \\
\hline \hline
\end{tabular}

According to Sekaran [21], it is necessary to obtain information from specific target groups through a purposive sampling method. Purposive sampling confined the selection of respondents to specific types of people who can provide the desired information, because they are the only ones who possess the information or because they conform to some criteria set by the researcher. For this research, the interview participants were selected on the basis of the following criteria:

(1) senior FM stakeholders who had substantial working experience in infrastructure projects, and

(2) senior FM stakeholders who were exposed to sustainability concepts in general.

Three respondents were involved as the participant in the semi-structured session. These three respondents were key players in FM with various roles and responsibilities in the selected infrastructure projects. These interviewees held senior positions in the project, namely, directors, chief operating officers, FM consultants and senior engineers. Before the interview was conducted, invitation letter, consent form, research framework and main questions were sent to the potential respondents to make sure they agreed to participate and to give them general ideas about the objectives of the interview. This is important to reduce interview time and to allow respondents to answer the questions more accurately. Table 2 lists the interviewees who participated in the semistructured interview.

TABLE II: Interviewee Profiles

\begin{tabular}{llll}
\hline \hline Interviewee ID & \multicolumn{1}{c}{ Role } & Type of Organization & Location \\
\hline R1 & Facility Manager & Consultant & Johor Bahru \\
R2 & Facility Manager & Developer & Johor Bahru \\
R3 & Chief Operating Officer & Developer & Kuala Lumpur \\
\hline \hline
\end{tabular}

\section{Research Findings}

Semi-structured interview was used as the tool to validate and explore in depth the critical factors of people capability that have the potential to support the implementation of sustainable FM in infrastructure project. This method allowed the respondents to have an overall view of the objectives of this research. As a result, Table 3 summarises the main findings extracted from the interview session in relation to each of the critical people capability factors. A set of guidelines to demonstrate the strategic actions and potential effects of each critical factors were then developed as discussed in the next sub-section. 
TABLE III: Main findings for top five PCap factors from semi-structured interview

\begin{tabular}{|c|c|c|}
\hline No. & People Capability Factor & Findings \\
\hline 1 & $\begin{array}{l}\text { Understand the Life Cycle Costing (LCC) } \\
\text { and Total Cost of Ownership (TCO) } \\
\text { technique }\end{array}$ & $\begin{array}{l}\text { - Client's need statement is translated } \\
\text { - Designer uses client's need as the term of reference in designing } \\
\text { - Advantageous characteristics of the PFI model } \\
\text { - Planning for the long-term and future use of the facility }\end{array}$ \\
\hline 2 & Understand the whole-life value concept & $\begin{array}{l}\text { - An important consideration to avoid unnecessary wastage and } \\
\text { unnecessary loss of opportunity } \\
\text { - The whole-life value concept can be employed as FM inputs are } \\
\text { considered during the design stage } \\
\text { - The whole-life value concept can be considered in the value } \\
\text { management exercise }\end{array}$ \\
\hline 3 & $\begin{array}{l}\text { Develop good relationships with the } \\
\text { organisation's top management }\end{array}$ & $\begin{array}{l}\text { - A structured system and process of communication can assist the } \\
\text { relationship with the top management. } \\
\text { - Kick-off meeting is the best platform to build a good relationship } \\
\text { - Good relationships help to influence the decision-maker in } \\
\text { infusing sustainability in the project }\end{array}$ \\
\hline 4 & $\begin{array}{l}\text { Understand the organisation's financial } \\
\text { strategy }\end{array}$ & $\begin{array}{l}\text { - Helps to convince the decision-maker to invest financially in the } \\
\text { sustainability efforts } \\
\text { - The proposed sustainability effort should tally with the project's } \\
\text { financial budget }\end{array}$ \\
\hline 5 & $\begin{array}{l}\text { Understand the design and construction } \\
\text { issues related to FM practice }\end{array}$ & $\begin{array}{l}\text { Help to solve the problem related to design (e.g. the usage of the } \\
\text { standard design or drawings) that will lead to maintainability } \\
\text { issues in the future } \\
\text { - FM personnel involvement during the design and construction } \\
\text { stage will support the sustainability effort } \\
\text { - In a PFI project, the FM personnel are given a fair chance to } \\
\text { contribute to the design } \\
\text { - FM personnel's input during the design and construction stage } \\
\text { needs to be appreciated, so that the agenda of sustainability is } \\
\text { taken into consideration }\end{array}$ \\
\hline
\end{tabular}

\subsection{Guidelines}

The information and ideas from the respondents in semi-structured interview sessions are important to get an insight view about the issues and factors in improving sustainable FM practice in infrastructure project. A set of questions were asked to the respondents on how can the people capability factors promote sustainability in FM practices.

\begin{tabular}{|c|c|c|}
\hline Category & Strategic actions & Potential effects \\
\hline $\begin{array}{l}\text { Strategic } \\
\text { capabilities }\end{array}$ & $\begin{array}{l}\text { - Consider the LCC and TCO concept in } \\
\text { accessing green alternatives } \\
\text { - Choose material that is durable and lasts for } \\
\text { a long time in order to have a good impact } \\
\text { on the total cost of ownership of a facility } \\
\text { - Improve communication skills } \\
\text { - Improve negotiation skills } \\
\text { - Involve during the planning, design and } \\
\text { - } \text { construction stage of project development } \\
\text { conport the implementation of life-cycle } \\
\text { involvement in project development }\end{array}$ & $\begin{array}{l}\text { - Reduce the building maintainability issue } \\
\text { - FM personnel have the opportunity to } \\
\text { contribute sustainability ideas such as in the } \\
\text { selection of material, equipment, machinery, } \\
\text { etc during the design stage of the } \\
\text { construction project } \\
\text { - Stimulate the improvement of the } \\
\text { procurement strategy that involves FM roles } \\
\text { in the early stage of the construction } \\
\text { development, such as: Private Finance } \\
\text { Initiative (PFI) / Public Private Partnership } \\
\text { (PPP) }\end{array}$ \\
\hline
\end{tabular}

Fig. 2: Example of the Actions and Effects Guidelines of PCap Factor.

During the interviews session, the experts were asked about the people capability factors in relation to: (1) what can be done to acquire capabilities to deal with these factors, and (2) how these factors can support the 
application of sustainability in their practice. Qualitative content analysis helped to analyse the information and facilitate the formulation of actions and potential effects guidelines for each of the critical people capability factors. Figure 2 shows an example of one of the 23 factors investigated in this research, which is "Understand the design and construction issues related to FM practice". The guidelines were formulated based on the codifying and categorising technique from the findings of the interviews. The Actions and Effects Guidelines were considered highly valuable in improving sustainable FM practices in infrastructure project. The guidelines can provide direction for FM personnel seeking to encapsulate the sustainability agenda in their practice.

\section{Conclusion}

While there is an increasing level of awareness to incorporate sustainability principles into FM practice in infrastructure project, this research found that, the industry professionals need to be equipped with proper knowledge, skills and capabilities to undertake the challenges associated with pursuing sustainable practice since these elements have been identified as their drawback. With such a background, people-centred approaches which have a good prospective to assist facility manager in this context are discussed in this paper. 23 critical people capability identified in the early stage of this research were further explored using semi-structured interviews. This paper has identified what can be done to acquire capabilities to deal with the critical people capability factors and how these factors can support the application of sustainability in their practice. Through the identification and integration of the different perceptions and priority needs of the experts who involved in infrastructure project, a set of guidelines was developed. In this paper, one of the factors, "Understand the design and construction issues related to FM practice", is shown to demonstrate an effectiveness of guidelines developed in improving FM professionals' capability in implementing sustainability in their practices. It is expected that these guidelines can provide direction for FM personnel seeking to encapsulate the sustainability agenda in their practice.

\section{Acknowledgements}

This research is supported under the Research Acculturation Grant Scheme (R061), Ministry of Higher Education Malaysia.

\section{References}

[1] T. Litman, "Developing indicators for comprehensive and sustainable transport planning". Transportation Research Record: Journal of the Transportation Research, pp. 10-15, 2007.

[2] K. Lothe, An Analysis of Constructability Strategies in Project Delivery: Making Infrastructure Construction Sustainable, in Copán Ruinas, Honduras, Vasa. 2006.

[3] R. Huang and C. Yeh, "Development of an Assessment Framework for Green Highway Construction," Journal of the Chinese Institute of Engineers, vol. 31(4), pp. 573-585, 2008.

https://doi.org/10.1080/02533839.2008.9671412

[4] National Research Council of the National Academies, Sustainable Critical Infrastructure Systems - A Framework for Meeting 21st Century Imperatives, Washington, D.C. pp. 58, 2009.

[5] Chartered Institute of Building (CIOB), Sustainability and construction, Ascot: Chartered Institute of Building, 2004.

[6] P. Hodges, “A facility manager's approach to sustainability” Journal of Facilities Management, vol. 3(4), pp. 312 324,2005

https://doi.org/10.1108/14725960510630498.

[7] Nielsen, Susanne Balslev, Jesper Ole Jensen and Per Anker Jensen, "Delivering Sustainable Facilities Management in Danish Housing Estates" presented at the 2nd International Conference on Sustainability Measurement and Modelling, Barcelona, Spain, 2009. 
[8] J. Lai and F. Yik, "Knowledge and perception of operation and maintenance practitioners in Hong Kong about sustainable buildings". Facilities, vol. 24, (3/4), pp. 90-105, 2006.

https://doi.org/10.1108/02632770610649368

[9] A. Elmualim, Czwakiel, Roberto Valle, Gordon Ludlow and Sunil Shah. "Barriers for implementing sustainable facilities management”. in Proc. 2008 World Sustainable Building Conference, 2008.

[10] S. Shah, Sustainable Practice for the facilities manager, Oxford; Malden, MA: Blackwell Publishing, 2007. https://doi.org/10.1002/9780470759677

[11] A. Elmualim, Czwakiel, Roberto Valle, Gordon Ludlow and Sunil Shah, "The Practice of Sustainable Facilities Management: Design Sentiments and the Knowledge Chasm'. Architectural Engineering and Design Management, vol. 5, pp. 91-102, 2009. https://doi.org/10.3763/aedm.2009.0909

[12] A. Elmualim, Daniel Shockley, Roberto Valle, Gordon Ludlow and Sunil Shah, "Barriers and commitment of facilities management profession to the sustainability agenda". Building and Environment, vol. 45, pp. 58-64, 2010. https://doi.org/10.1016/j.buildenv.2009.05.002

[13] N. Sarpin and J. Yang, "People capabilities for promoting sustainability in facilities management practices". In Proc. 2013 World Building Congress, 2013.

[14] A. Elmualim, "Sustainability in FM: Trends in policy and FM competence consequences". In Proc. 2013 World Building Congress, 2013.

[15] N. Sarpin and J. Yang, "A framework for people capability enhancement to support sustainable facility management practices". In Proc. 2014 Pich-Aguilera, Felipe (Ed.) Proceedings of the World Sustainable Building Conference, 2014.

[16] N. Sarpin, J. Yang and Xia, Bo, "Developing people capability framework to promote sustainability in facility management practices". Facilities, vol. 34 Iss 7/8 pp. 450 - 467, 2016. https://doi.org/10.1108/F-05-2014-0044

[17] J. Adams, Khan, H, Paeside, R and White, D, "Research methods for graduate business and social science students". Writing, vol.14, (3), pp. 161-164, 2010.

[18] M. Saunders, Philip Lewis and Adrian Thornhill, Research methods for business students. 5th ed. England: Pearson Education Limited, 2009.

[19] T. Wengraf, Qualitative research interviewing. SAGE Publications, Inc., London, 2001. https://doi.org/10.4135/9781849209717

[20] C. Robson, Real world research. 2nd ed: Blackwell Publishers Inc., USA, 2002.

[21] U. Sekaran, Research methods for business: A skill-building approach. NYC: John Willey Sons: Inc., 2003. 